\title{
GENDER-BASED ON STAIN OF WATAMPONE LECTURERS PERFORMANCE IN THE EFL CLASS
}

\author{
Aschawir Ali* \\ * English Departement of STAIN Watanpone \\ Email: aschawir(a!vahoo.co.id
}

Koreksi naskah I tanggal 20 Juni 2012. Koreksi naskah II tanggal 28 Juni 2012. Finalisasi Naskah 9 Oktober 2012

\begin{abstract}
The concept of modern teachers and the development of ideas such as 'professionalism teacher" historically is genderized and more often reflects the paradigm of political theory or patrilinialism. At the same time, research shows that gender as a relevant variable is more focused on the function of the class and the teacher-student interaction. This study aimed to determine the effect of the gender of teachers to English students who are learning foreign language (EFL), particularly at the high school of Islam that has its own challenges and contradictions of gender paradigm of gender itself Contextual investigation showed that the development of democratic and learning about democracy more often grab to the feminism, while the more traditional prescriptive environment often associated with masculinity that is considered less helpful in getting the success in the learning process.
\end{abstract}

Keywords: Learning Language, English, gender of teachers, gender-based performance

\section{INTRODUCTION}

$\mathrm{E}$ pistemologically in socio-educational field, there are many opinions about lecturers' profession alism that has to be based on male gender political concepts. This is reflected in our collage (State Collage of Islamic Studies in Watampone). One of reflections that was Dillabough' said that gender and the history of male domination in political thought are crucial if we understand that the traits of modern-day schooling. This contemporary notion of professionalism is conceived as the rational capacity to behave in a competent and efficient way in order to obtain an adequate level of effort from students; thus, the lecturers' professional contribute to the attainment of objectives proposed by the neo-liberal democracy and thereby encourages desired social and economic change; such as: developments have the potential to undermine lecturers" political authenticity and it can essentially lead to forms of technical control.

In this matter, there are some attempts as an alternative way to minimilaze the masculinism domination by feminist in particularly about political theory how rationale and competent the male lecturers to female lecturers. But mostly it lies down by government that as a gender model properly and professionally to all the lecturers. It is still arguably that the aim of this matters have to be broken away particularly the traditions irrationally or no pure paradigms. The core of this matters that we have to have the concept of social constructivism.

However, while steps are being taken to raise awareness of the gender factor in teaching and learning and although certain progress has been made, in practical terms; traditionally gendered views on instruction still lead to the underestimating of the profession itself and even bring about a questionable gender-based distribution of lecturer at certain academic levels. Furthermore, current trends in effectiveness and performance in education appear to be remasculinising already gendered policies. As a number of authors suggest many elements employed both in the philosophy and within the very discourse of educational performance management are still discriminatory.

Then, introduced mechanisms aimed at removing gender bias, while at the same time investigating

\footnotetext{
' Jo-Anne Dillabough. Gender Politics and Conceptions of the Modern Teacher: Women, Identity and Professionalism. 1999. British Journal of Sociology of Education, p, 373-392.
}

' (n) Gender bias is the prejudice in action or treatment against a person on the basis of their sex. Eg. Payment of lesser salary to weaker sex workers. 
nation-wide programmes to enhance the quality of education based on performance management strategies previously employed in the collage. As mentioned, however, the nature of the latter has arguably contributed to a remasculinisation of the teaching profession in other contexts. Thus, it is posited here that the possible benefits that may be obtained by these trends may be detrimental to those social aspects which educational administrations theoretically strive to offer, including that of gender equity.

While taking into consideration these changes in the education system, this study attempts to address a number of questions related to how the gender factor influences the interaction and perspectives which exist between lecturers and students in the EFL class and aims to identify which characteristics are most closely associated with improved student satisfaction and performance.

\section{STUDIES ON GENDER IN TEACHING AND LEARNING}

There are some important studies that prove the gender of both the teacher and the student is a relevant variable that must be considered when explaining the function of classes and the types of interaction which occurs therein. For example, McAuliffe ${ }^{3}$ and $\mathrm{Kamler}^{4}$ found that the characters depicted in pieces of written work carried out by students often reflect certain gender stereotypes. Furthermore, in examining group discussions among students, Evans ${ }^{5}$ has shown that there is an abundance of individual beliefs on gender domination and subordination which allows some people to be heard more than others. A number of these studies are supported by research in ELT. For example, it has been shown that male language learners tend to dominate conversations and produce more language output; female students, on the other hand, tend to initiate more conversations and receive more input.

The context of education that the gender stereotyping has been shown to exist not only among teachers and learners but also in the elaboration of classroom materials, including textbooks and, more recently; in educational software for young children. Language teaching has also had its share of stereotyping and indeed, bias; as we can observe in Leskin's ${ }^{6}$ examination of popular ESL textbooks. As in other subject areas, the use of gender biased resources, which are often widely accepted by teachers, essentially leads to systematic and often unconscious perpetuation of the inappropriate treatment of gender in teaching and learning. It has been noted that unless appropriate steps are taken to raise awareness of practices such as gender stereotyping and indeed, to rectify them; students are likely to reproduce them.

"Sitting in the same classroom, reading the same textbook, listening to the same teacher, boys and girls receive very different educations." Sadker?. In fact, upon entering school, girls perform equal to or better than boys on nearly every measure of achievement, but by the time they graduate high school or college, they have fallen behind. However, discrepancies between the performance of girls and the performance of boys in elementary education leads some critics to argue that boys are being neglected within the education system.

The act of interacting with gender in our campus assures that girls are made aware that they are unequal to boys. Every time students are seated or lined up by gender, teachers are affirming that girls and boys should be treated differently. When an administrator ignores an act of sexual harassment, he or she is allowing the degradation of girls. When different behaviors are tolerated for boys than for girls because 'boys will be boys', the campus are to prolong the existence of the unjust manner of females. There is some evidence that girls are becoming more academically successful than boys, however examination of the classroom shows that girls and boys continue to be socialized in ways that work against gender equity.

Lecturers socialize girls towards a feminine ideal. Girls are praised for being neat, quiet, and calm, whereas boys are encouraged to think independently, be active and speak up. Girls are socialized in schools to recognize popularity as being important, and learn that educational performance and ability are not as important. "Girls in grades six and seven rate being

\footnotetext{
'McAuliffe S. 1994. Toward understanding one another: second graders' use of gendered language and story styles. 1994. 
popular and well-liked as more important than being perceived as competent or independent. Boys, on the other hand, are more likely to rank independence and competence as more important." Bailey.

\section{GENDER POLICIES}

The gender stereotyping dominations are areas which are often filled with controversy. Various educators, for example: believe that the socialisation of gender roles is primarily a function which should be addressed at home with the family, consequently; the school should remain neutral. If we were to concur with this position, a natural conclusion would be to suggest that the school must treat all students equally, leaving freedom of choice in the adoption of roles. However, there are those thinking that the collage should not remain indifferent and argue instead for the promotion of behaviours which reflect the values of society and the school itself; this position would likely support the existence of a gender policy within schools. Among the teachers who do to support a gender policy there is a debate between those who are in favour of equity and those who defend equality. Those who support equality believe that all students must have equal opportunities to access resources and to participate in activities. Those who are in favour of equity believe that weaker groups must be favoured in order to increase their chances of reaching the same level as those in a more privileged position.

This essentially represents a compensatory policy which encourages equality. Both options are problematic, since there are those who do not feel comfortable treating groups of students in different ways, and others who consider it unfair to give the same treatment to different groups who do not have the same options open to them. Perhaps the ideal solution would be a combination of equity and egalitarian practices whereby the same opportunities are given to all students and special attention given to groups with specific needs. Either way, it would appear that the construction of a gender policy in collage is of fundamental importance if we are to raise awareness of gender issues and to enable individual and groups of teachers and students to consciously prevent and challenge discriminatory behaviours.

\section{LECTURERS' TREATMENT OF GENDER IS- SUES}

The way in approaching of gender related issues will very much depend on their own perceptions of gender. Some lecturers, for example, believe that differences between male and female students are originated by purely biological motives, others attribute gender differences to socialisation processes, and there are a number of eclectics who attempts to combine the reasons from both sectors. In terms of specific treatment of gender in the classroom, Alverman et al. and Evans ${ }^{9}$ have found that the teacher often attempts to strike a balance in debates with students about gender-related themes by introducing some points of view, without imposing them, and allowing students to adopt their own personal positions. Commeyras et al. ${ }^{10}$ discovered that $86 \%$ of teaching staffs felt more at ease) monitoring equal participation between boys and girls) including the work of boys and girls who belonged to another lower level group in curricular tasks. At the same time, however, a large sector of the teaching staffs felt uncomfortable debating controversial themes such as sexist language or the identification of students with characters of the same gender. This study reflects the teacher's interest in applying egalitarian gender strategies, but it also indicates that instructors may feel reluctant to deal with gender- related themes because of the controversy they produce.

\section{GENDER AND LECTURERS BEHAVIOUR}

In terms of lecturers gender and its effect on students, research such as that conducted by Wilkinson and Marret ${ }^{11}$ has shown that this variable must be taken into account when attempting to explain perceptions and behaviours in schools. As far as the gender factor and interaction between instructors and students is concerned, various studies indicate that boys and girls are treated differently by their teachers. Brophy and Meece ${ }^{12}$ have shown that teachers pay more attention to boys, give them more answers in public, praise them more frequently and criticise them more harshly when they under-perform or behave badly. Their research concludes that the differential behaviour of teachers is a consequence of gender dif-

\footnotetext{
Bailey, S. How Schools Shortchange Girls. 1992.

Alverman D, Commeyras M, Young J, Hinson D, Randall S. Interrupting gendered discursive practices in classroom talk about texts: Essay to think about, difficult to do. 1996.

10 Commeyras M, Young J, Hinson D. Educators stances toward gender issues in literacy. Paper presented at the Annual Meeting of the American Educational Research Association. 1997.

$"$ Wilkinson LC, Marret CB. Gender influences in classroom interaction. 1985.

12 Brophy J. Interactions of male and female students with male and female teachers. 1985.
} 
ferences in the behaviour of the students. The others studies have also found that gender differences in students are related to and interact with academic success, interests, classroom behaviour, race, and thematic content of subjects taught. Lawrenz ${ }^{13}$ has indicated that, in secondary level education, girls perceive the psychological environment of the class to be more helpable when they have a male teacher, while the boys are more comfortable with a female teacher. Both the gender of the students and the teacher affect their mutual relationship in the classroom. With this general hypothesis in mind, Hopf and Hatzichristou ${ }^{14}$ carried out studies in Greece with 1041 primary school students and 862 secondary school students in order to examine the extent to which teacher-student interaction is affected by teacher gender.

Their results showed the existence of significant differences arising from the gender of the teacher when it comes to assessing student competence. Furthermore, female teachers tended to employ a greater number of gender stereotypes in their attitude and expectations with regards to student behaviour and frequently adopted stereotypical roles more, closely associated with the female gender: they acted as maternal figures, showing a large degree of protection towards the children as well as greater understanding towards their bad behaviour. In secondary education the female teachers were more sympathetic to the problems of students who performed poorly and attributed a higher level of importance to the interpersonal problems of students than the male teachers.

This behaviour has been reported in other investigations which have shown a higher degree of sensitivity towards student behavioural problems by female teachers as well as Jones and Wheatley's ${ }^{15}$ observation of their tendency to give more advice or warnings with regards to male students. At the same time, it is possible that male teachers control aggressive gestures, disobedience and indiscipline at the adolescent stage more easily than the female teachers, although the female teachers were shown to be more adept and effective at the primary level. It was also found that teachers assessed interpersonal problems between members of the opposite sex as being less problematic than those between members of the same sex, although this is a more difficult matter to interpret. Male teachers showed a more authoritarian and academically task-focused teaching style, while the female teachers showed a more expressive style, lent a greater degree of support towards the students and placed less emphasis on tasks, as seen in the work of Good, Sikes and Brophy ${ }^{16}$. Where student perceptions are concerned, Hopf and Hatzichristou's study indicated that different aspects of student self-concept changed depending on the gender of the teacher: the self-concept of adolescents and their relationship with their classmates were more positive with teachers of the opposite sex. This view coincided with the perceptions of the teachers. Furthermore, it was observed that students from groups with a female teacher had a relatively higher, more positive self-concept in terms of physical appearance, academic achievement and their relationship with their parents than those who had a male teacher.

In Great Britain, Younger, Warrington and Williams ${ }^{17}$ have also studied the variable of gender in relation to class interactions at secondary school level. Despite the fact that the teachers involved claim to treat boys and girls equally and while they say that little attention is paid to differences derived from gender, the results provided tend to show otherwise. The first of a number of discrepancies mentioned in this study lies in the fact that girls academically outperform boys at Primary and Secondary levels. Among the causes that could explain this difference, experts in the field point to the following: a greater lack of concern on the part of boys towards teacher authority, academic work and performance; more negative attitudes towards work, and lower objectives and aspirations, a greater degree of maturity and more effective learning strategies in girls. Similar findings with regards to academic performance among girls have also been presented in literature on FL learning. In Britain, for example, in 1999 the Office for National Statistics pointed to the fact that girls consistently outperform boys in GCSE and A level examinations in

13 Lawrenz F. Gender effects for student perception of the classroom psychosocial environment. 1987.

${ }^{14}$ Hopf D, Hatzichristou C. Teacher gender-related influences in Greek schools. 1999.

is Jones, MG, Wheatley, J. Gender differences in teacher-student interactions in science classrooms. 1990.

${ }^{16}$ Good TL, Sikes JN, Brophy JE. Effects of teacher sex and student sex on classroom interaction. 1973.

"Williams M, Burden R, Lanvers $U$. 'French is the language of love and stuff: student perceptions of issues related to motivation in learning a foreign language. 2002 . 
ferences in the behaviour of the students. The others studies have also found that gender differences in students are related to and interact with academic success, interests, classroom behaviour, race, and thematic content of subjects taught. Lawren $z^{13}$ has indicated that, in secondary level education, girls perceive the psychological environment of the class to be more helpable when they have a male teacher, while the boys are more comfortable with a female teacher. Both the gender of the students and the teacher affect their mutual relationship in the classroom. With this general hypothesis in mind, Hopf and Hatzichristou ${ }^{14}$ carried out studies in Greece with 1041 primary school students and 862 secondary school students in order to examine the extent to which teacher-student interaction is affected by teacher gender.

Their results showed the existence of significant differences arising from the gender of the teacher when it comes to assessing student competence. Furthermore, female teachers tended to employ a greater number of gender stereotypes in their attitude and expectations with regards to student behaviour and frequently adopted stereotypical roles more, closely associated with the female gender: they acted as maternal figures, showing a large degree of protection towards the children as well as greater understanding towards their bad behaviour. In secondary education the female teachers were more sympathetic to the problems of students who performed poorly and attributed a higher level of importance to the interpersonal problems of students than the male teachers.

This behaviour has been reported in other investigations which have shown a higher degree of sensitivity towards student behavioural problems by female teachers as well as Jones and Wheatley's ${ }^{15}$ observation of their tendency to give more advice or warnings with regards to male students. At the same time, it is possible that male teachers control aggressive gestures, disobedience and indiscipline at the adolescent stage more easily than the female teachers, although the female teachers were shown to be more adept and effective at the primary level. It was also found that teachers assessed interpersonal problems between members of the opposite sex as being less problematic than those between members of the same sex, although this is a more difficult matter to interpret. Male teachers showed a more authoritarian and academically task-focused teaching style, while the female teachers showed a more expressive style, lent a greater degree of support towards the students and placed less emphasis on tasks, as seen in the work of Good, Sikes and Brophy ${ }^{16}$. Where student perceptions are concerned, Hopf and Hatzichristou's study indicated that different aspects of student self-concept changed depending on the gender of the teacher: the self-concept of adolescents and their relationship with their classmates were more positive with teachers of the opposite sex. This view coincided with the perceptions of the teachers. Furthermore, it was observed that students from groups with a female teacher had a relatively higher, more positive self-concept in terms of physical appearance, academic achievement and their relationship with their parents than those who had a male teacher.

In Great Britain, Younger, Warrington and Williams ${ }^{17}$ have also studied the variable of gender in relation to class interactions at secondary school level. Despite the fact that the teachers involved claim to treat boys and girls equally and while they say that little attention is paid to differences derived from gender, the results provided tend to show otherwise. The first of a number of discrepancies mentioned in this study lies in the fact that girls academically outperform boys at Primary and Secondary levels. Among the causes that could explain this difference, experts in the field point to the following: a greater lack of concern on the part of boys towards teacher authority, academic work and performance; more negative attitudes towards work, and lower objectives and aspirations, a greater degree of maturity and more effective learning strategies in girls. Similar findings with regards to academic performance among girls have also been presented in literature on FL learning. In Britain, for example, in 1999 the Office for National Statistics pointed to the fact that girls consistently outperform boys in GCSE and A level examinations in

\footnotetext{
${ }^{13}$ Lawrenz F. Gender effects for student perception of the classroom psychosocial environment. 1987.

${ }^{14}$ Hopf D, Hatzichristou C. Teacher gender-related influences in Greek schools. 1999.

${ }^{15}$ Jones, MG, Wheatley, J. Gender differences in teacher-student interactions in science classrooms. 1990.

${ }^{16}$ Good TL, Sikes JN, Brophy JE. Effects of teacher sex and student sex on classroom interaction. 1973.

17 Williams M, Burden R, Lanvers $U$. 'French is the language of love and stuff: student perceptions of issues related to motivation in learning a foreign language. 2002 .
} 
modern languages. Among the reasons for the differences in outcomes in language learning, girls appear to have more a more positive attitude towards language learning while boys may have a tendency to see language subjects as being too feminine. Younger, Warrington and Williams also point out that boys behave in a different way from girls and, consequently, teachers treat them in a different way. Girls, for example, were better organised, they showed more sophisticated communicative skills, they had higher levels of selfconfidence and performed better in independent work sessions. The teachers perceived the girls as having a higher level of capacity for autonomous learning, a greater level of dedication to academic tasks at home and better planning of work. These differences in cognitive style have also been underlined by Head. In contrast, boys were perceived in a more negative light: many staff saw many boys as presenting an opposite image, more disordered, more demotivated, less willing to prioritise school work, more vocal, more noisy, less advanced for their years, more easily distracted than girls.

Furthermore, male students were shown to be more concerned with their image within the group and were more likely to question both the type of education they received and the ethics of the school. Boys perceived that they received a more negative treatment from teachers than girls and they believed girls to be more critically discerning, outwardly showing behaviour which they did not later put into practice. They approached male teachers and posed their problems in such a manner that they 'got their own way'. Girls, however, saw themselves in a more constructive light; they took the initiative more often and asked for clarifications more frequently. While teachers may express that they pay little attention to gender differences in the classroom, a number of scholars, including Ropers-Huilman and Weiler ${ }^{18}$ have stated that teachers' identities do influence their teaching practice. Their own background and their status in relation to their gender affect the ways in which they construct their teaching behaviour, their interaction and relations with their students. The teachers' identity as male or female is closely related to authority in the classroom and educators have expressed the concern that students often consider male teachers as authoritarian and female teachers as too soft and unable to control some undisciplined situations. As we will see at a later point, our research study provides collects similar perceptions held by students and teachers in terms of the gender factor and classroom management.

\section{CONTEXTUALISED INVESTIGATION}

Taking into the context of this investigation, in which recent legislative changes place high levels of importance on gender equity and performance management, our aim in this study is to conceptualise how individual male and female students and lecturers perceive the effectiveness of their learning in relation to the gender of teachers. The exploration of student and lecturers perceptions, then; is measured around the questions as to whether male and female students work better and/or learn more with male or female teachers and whether differences are to be found at different academic levels.

Variable 1. Respondent's preference for male teachers and the incidence of this in T/LEFL

Variable 2. Respondent's preference for female teachers and the incidence of this in $\mathrm{T} /$ LEFL

Variable 3. Perception that male students prefer female English teachers.

Variable 4. Perception that female students prefer male English teachers.

Collage: Year:

$\mathrm{N}^{\circ}$ list: ......Sex: M. ... F. ..... Date:

Express your opinion on the influence of the following aspects on students' learning.

\section{QUALITATIVE PART}

1. What influence does the gender of the teachers have on the way they act in English class?

2. Who are better, male teachers or female teachers? Who obtains better results in English class?

\section{QUANTITATIVE PART}

Now express your opinion on the following using this scale:

$$
\begin{aligned}
& 4=\text { always } \\
& 3=\text { almost always } \\
& 2=\text { sometimes } \\
& 1=\text { hardly ever } \\
& 0=\text { never }
\end{aligned}
$$


1. Male English teachers are better than female teachers and you learn more with them (....)

2. Female English teachers are better than male teachers and you learn more with them (....)

3. Boys work better with female teachers than with male teachers and learn more with them (....)

4. Girls work better with male teachers and learn more with them (....)

The questionnaires were applied in a total of three classes of fourth semester and three classes of sixth semester voluntary participating in this institutions in Watampone and included 111 students respondents and 8 lecturers respondents (Tables 1 and 2).

Table 1.

Descriptive Statistics for Students

\begin{tabular}{|c|c|c|c|c|c|c|c|}
\hline $\begin{array}{c}\text { State School of } \\
\text { Islamic Studies of } \\
\text { Watampone }\end{array}$ & $\begin{array}{c}\text { TBI } \\
\mathbf{1 - S J}\end{array}$ & $\begin{array}{c}\text { TBI } \\
\mathbf{2 - S 3}\end{array}$ & $\begin{array}{c}\text { TBI 3- } \\
\mathbf{S . 3}\end{array}$ & $\begin{array}{c}\text { TBI } \\
\mathbf{1 -} \\
\mathbf{2 / S . 6}\end{array}$ & $\begin{array}{c}\text { TBI } \\
\mathbf{3 -} \\
\mathbf{4} / \mathbf{S . 6}\end{array}$ & $\begin{array}{c}\text { TBI } \\
\mathbf{5 -} \\
\mathbf{6 / S . 6}\end{array}$ & TOTAL \\
\hline Male & 7 & 7 & 6 & 7 & 8 & 4 & $\mathbf{3 9}$ \\
\hline Female & 9 & 14 & 12 & 12 & 10 & 15 & 72 \\
\hline TOTAL & $\mathbf{1 6}$ & $\mathbf{2 1}$ & $\mathbf{1 8}$ & $\mathbf{1 9}$ & $\mathbf{1 8}$ & $\mathbf{1 9}$ & $\mathbf{1 1 1}$ \\
\hline
\end{tabular}

Table 2.

\section{Case Summary of Teacher Sample}

\begin{tabular}{|c|l|c|c|}
\hline No. & \multicolumn{1}{|c|}{ Teachers } & N & \% \\
\hline $\mathbf{1 .}$ & Types of Institutions & 1 & 8 \\
\hline & $\begin{array}{l}\text { State Collage of Islamic Studies of } \\
\text { Watampone }\end{array}$ & & \\
\hline $\mathbf{2 .}$ & Academic Level & & \\
\hline & Bachilleralo or 'A' level equivalent & 1 & 8 \\
\hline $\mathbf{3 .}$ & Gender & & \\
\hline & Male teachers & 39 & 487.5 \\
\hline & Female teachers & 72 & 900 \\
\hline $\mathbf{4 .}$ & Age & & \\
\hline & $20-30$ & 2 & 25 \\
\hline & $31-40$ & 4 & 50 \\
\hline & $41-50$ & 2 & 25 \\
\hline & More than 50 & & \\
\hline $\mathbf{5 .}$ & Teaching body & 3 & 37.5 \\
\hline & Fourth Semester & 3 & 37.5 \\
\hline & Sixth Semester & $\mathbf{8}$ & $\mathbf{1 0 0 \%}$ \\
\hline & Total & & \\
\hline
\end{tabular}

*Formula: Teachers $\mathrm{N} \%$

\section{DISCUSSION AND CONCLUSIONS}

Male and female teachers and male and female students coincide in expressing their belief that there is no great differences in the performance and functioning of the teacher in terms of gender. However, both male and female students concur in their own beliefs that they learn more with female teachers, a view which is not shared by teachers, who perceive no significant difference between genders. Nevertheless, when differences are stated, these tend to sug- gest that there is a perception that male teachers are more authoritarian yet obtain poorer results, while female teachers are more supportive, better accepted and obtain better results. Both teachers and students have highlighted certain differences caused by gender in class interaction: some boys are shier with female teachers and are more careful when they approach a female teacher. In the case of girls, it is possible that they try to gain the male teacher's attention. Particularly with the quantitative results, it is also observed that boys tend to show a certain preference for female teachers, while the preference of girls for male teachers is less.

There are also significant differences between male and female teachers in the variable which controls the preference of boys for female teachers and the preference of girls for male teachers. In contrast, however, female teachers and female students in this study do not share this opinion and do not perceive this preference. As we have already mentioned, it is interesting how both male teachers and male students consider the variable of gender to be more relevant and find more differences between men and women than female subjects. The two most important elements of our study, however, appear to be the fact that students believe that they learn more with female teachers; this is particularly true in the case of female students. At the same time they see a number of characteristics which are traditionally considered to be masculine (such as the imposition of respect and authority) in a negative light and highlight in positive terms the aspects of trust and acceptance associated in this study with the female teacher.

There is a perception that male teachers in the context in question appear to be more authoritarian and academically focused, while the female teachers are shown as being more supportive. Our reading of our specific learning context suggest that the resulting sociopsychological environment stimulated by the presence of conscious or subconscious pedagogical strategies employed by teachers may have led to the students' perception that they learn more with female rather than with male teachers. This stands in contrast to previous studies which have indicated that both male and female students prefer to learn with teachers of the opposite sex. While the subjects in our study often pointed to the fact that male teachers were able to have more authority in class, this did not mean that students felt they learned more with them; indeed, it appears that the opposite is the case. 
In a study carried out by Jules and Kutnick ${ }^{19}$, one of the key aspects of good teaching lay in the quality of the teacher-student relationship; our study would suggest that the quality of this relationship in our context is perceived to be higher with female teachers than with male teachers. Among the possible factors which may contribute to this situation, and which have been detected in the qualitative part of our study, is the belief that female teachers are regarded as being less strict, are closer to the students and more attentive to their individual needs. There should be a greater deal of implementation of pedagogical strategies in the education of boys 'which foster more discussion and collaboration in the classroom, and which support cooperative and interactive teaching and learning'. In our context, we have found that both male and female students tend to feel more comfortable in such learning contexts which are less strict and authoritarian. To a large degree in attributing female teachers with qualities which more readily enable them to provide supportive environments. It becomes clear that these qualities and practices are in fact extremely important, but not because they are natural and instinctive; caring must be learned. And they are not "soft," not the "opposite" of, or at another extreme from academic rigor. Rather, they are a central quality of a demanding and successful teacher, whether male or female. There are obvious limitations to what we are able to conclude from the research which we have undertaken. The most important of these, in our view, is the fact that the student perceptions are, by nature, subjective, and are not supported by quantitative external evidence to suggest that more learning does, Indeed, take place with female teachers.

At the same time, this subjective opinion is not shared by the teachers themselves. Nevertheless, the fact that students do express that they learn more with female teachers in itself may constitute an indirect indicator of student preferences for certain teaching styles and learning environments. If we are to accept existing evidence which suggests that positive learning environments go hand in hand with positive learner performance and if we are to draw any pedagogical conclusions from this study, we would tentatively state that there are indications that a number of attitudes adopted and strategies employed by female teachers in this specific context seem to enhance the sociopsychological environment which may lead to higher levels of satisfaction with the learning process.
Whether or not students actually learn more with female teachers in our context is a question which requires further research. While much of what we have concluded with regards to the learning environment may seem obvious, other aspects of our study, such as the rejection of the hypothesis that students, both male and female, prefer teachers of the opposite sex, are perhaps, not as common. In either case, we feel that it is worthwhile to bring these issues and perceptions to the attention of practising teachers particularly in our own context in the hope is that it will provoke self-questioning, examinations of practice, changes in patterns of instructional behaviour where appropriate, and further investigation into the effects of gender on teaching and learning.

On a final note, we would mention that as we enter new stages of quality control, target-setting and the measurement of global performance figures, it is important that certain beneficial instructional qualities are not obviated and that control is not equated with authoritarianism and individualism. Instead, we must continually remind ourselves of the need for more democratic, understanding and cooperative forms of teaching and learning in which positive environments are not sacrificed in the quest for obtaining everincreasing demands on performance.

\section{REFERENCES}

Dillabough, J. (1999). Gender Politics and Conceptions of the Modern Teacher: Women, Identity and Professionalism. British Journal of Sociology of Education, 20(3), 373-392.

Maher, Frances A Gender and Teaching. Lawrence Erlbaum Associates: Mahwah, NJ 2002.

Forrester G. All in a day's work: primary teachers 'performing' and 'caring'. GendEduc 2005; 17: 271-87.

Mahony P, Hextall I, Menter I. Threshold assessment and performance management: modernizing or masculinizing teaching inEngland?GendEduc2004; 16: 131-49.

McAuliffe S. Toward understanding one another: second graders'use of gendered language and story styles. Read Teach 1994; 47:302-10.

Kamler B. Constructing gender in the process writing classroom. Lang Arts 1993;70:95-103.

Evans K. Creating spaces for equity? The role of positioning in peer led literature discussions. Lang Arts 1966; 73: 194-202.

Gass S, Varonis E. Sex differences in non-native speaker-nonnative speaker interaction. In: Day R, Ed. Talking to learn: conversations in second language acquisition, Newbury House, Rowley, Mass 1986; pp.327-52.

${ }^{19}$ Dr. Vena Jules and Peter Kutnick. Student Perceptions of a Good Teacher: The gender Perspective. British Journal of Educational Psychology. 1997. 67, 497-511. 
Davis B. Gender bias in school text books. Commonwealth Secretariat. London 1995.

Sheldon J. Gender stereotypes in educational software for young children. Sex Roles 2004; 51:433^4.

Leskin J. Determining social prominence: a methodology for uncovering gender bias in ESL textbooks. In: Hall D, Hewings A, Eds. Innovation in English language teaching: a reader, Routledge, New York 2001; pp. 275-83.

Manjari S. Gender issues in the language arts classroom. Eric Digest. 1998. Accessed 21 April, 2009. Available from http:/ /www.ericdigests.org/ 1999-3/issues.htm

Streitmatter J. Toward gender equity in the classroom: everyday teachers' beliefs and practices. State University of New York Press. New York 1994.

Alverman D, Commeyras M, Young J, Hinson D, Randall S. Interrupting gendered discursive practices in classroom talk about texts: Essay to think about, difficult to do. Athens, Georgia: National Reading Research Center 1996.

Commeyras M, Young J, Hinson D. Educators stances toward gender issues in literacy. Paper presented at the Annual Meeting of the American Educational Research Association, 1997 March; Chicago, Illinois, 1997.

Wilkinson LC, Marret CB. Gender influences in classroom interaction. New York: Academic Press. New York 1985.

Brophy J. Interactions of male and female students with male and female teachers. In: Wilkinson LC, Marret CB, Eds. Gender influences in classroom interaction, Academic Press New York 1985; pp. 115-42.

Meece JL. The influence of school experiences on the development of gender schemata. In: Liben LS, Signorella ML, Eds. Children's gender schemata. Pennsylvania State University. San Francisco 1987; pp. 57-73.

Baumert J. Koedukation oder, geschlechtertrennung. Zeitschrift fiirpadagogik 1992; 38: 83-110.

Lawrenz F. Gender effects for student perception of the classroom psychosocial environment. J Res Sci Teach 1987; 24: 689-97.

Hopf D, Hatzichristou C. Teacher gender-related influences in Greek schools. Br J Educ Psychol 1999; 69: 1-18.

Ritter DR. Teacher's perceptions of problem behavior in general and special education. Except Child 1989; 55: 559-64.

Jones, MG, Wheatley, J. Gender differences in teacher-student interactions in science classrooms. J Res Sci Teach 1990; 27: 861-74.

Good TL, Sikes JN, Brophy JE. Effects of teacher sex and student sex on classroom interaction. J Educ Psychol 1973; 65:74-87.

Younger M, Warrington M. Differential achievement of girls and boys at GCSE: some observations from the perspective of one school. Br J Sociol Educ 1996; 17: 299-314.

Arnot M, David M, Weiner G. Educational Reforms and Gender Equality in Schools. Equal Opportunities Committee. Manchester 1996.

Turner E, Riddell S, Brown S. Gender equity in Scottish schools: the impact of recent educational reforms. Equal Opportunities Commission. Manchester 1995.

Riddell S. Boys and under-achtevement: the Scottish dimension. Inter J Inclu Educ 1998; 2: 169-86
Harris S, Nixon J, Rudduck J. Schoolwork, homework and gender. Gend Educ 1993;5:3-15.

Rudduck J, Chaplain R, Wallace G. School improvement: what can students tell us? David Fulton. London 1995.

Younger M, Warrington M, Williams J. The gender gap and classroom interactions: reality and rhetoric? Br J Sociol Educ 1999; 20:325-41.

Gipps C. Review and conclusions: a pedagogy or a range of pedagogic strategies? In: Murphy PF, Gipps CV, Eds. Equity in the classroom: towards effective pedagogy for girls and boys, Falmer Press. London 1996; pp. 260-71.

Williams M, Burden R, Lanvers U. 'French is the language of love and stuff': student perceptions of issues related to motivation in learning a foreign language. Br Educ Res J 2002; 28: 503-28.

Burstall C. Factors affecting foreign language-learning: a consideration of some relevant research findings, Language Teaching and Linguistics Abstracts. 1975; 8: 105-25.

Head J. Gender identity and cognitive style. In: Murphy PF, Gipps CV, Eds. Equity in the classroom: towards effective pedagogy for girls and boys, Falmer Press. London 1996; pp. $59-70$.

Ropers-Huilman B. Constructing feminist teachers: complexities of identity. Gend Educ 1997; 9: 327^3.

Weiler K. Women teaching for change: gender, class and power. Bergin and Garvey. New York 1988.

Jules V, Kutnick P. Student perceptions of a good teacher: the gender perspective. Br J Educ Psychol 1997; 67: 497-511.

Haertel GD, Walberg HJ, Haertel EH. Socio-psychological environments and learning: a quantitative synthesis. Br Educ Res J 1981; 7: 27-36. 
Davis B. Gender bias in school text books. Commonwealth Secretariat. London 1995.

Sheldon J. Gender stereotypes in educational software for young children. Sex Roles 2004; 51: 43344.

Leskin J. Determining social prominence: a methodology for uncovering gender bias in ESL textbooks. In: Hall D, Hewings A, Eds. Innovation in English language teaching: a reader, Routledge, New York 2001; pp. 275-83.

Manjari S. Gender issues in the language arts classroom. Eric Digest. 1998. Accessed 21 April, 2009. Available from http:/ 'www.ericdigests.org/ 1999-3/issues.htm

Streitmatter J. Toward gender equity in the classroom: everyday teachers' beliefs and practices. State University of New York Press. New York 1994.

Alverman D, Commeyras M, Young J, Hinson D, Randall S. Interrupting gendered discursive practices in classroom talk about texts: Essay to think about, difficult to do. Athens, Georgia: National Reading Research Center 1996.

Commeyras M, Young J, Hinson D. Educators stances toward gender issues in literacy. Paper presented at the Annual Meeting of the American Educational Research Association, 1997 March; Chicago, Illinois, 1997.

Wilkinson LC, Marret CB. Gender influences in classroom interaction. New York: Academic Press. New York 1985.

Brophy J. Interactions of male and female students with.male and female teachers. In: Wilkinson LC, Marret CB, Eds. Gender influences in classroom interaction, Academic Press New York 1985; pp. 115-42.

Meece JL. The influence of school experiences on the development of gender schemata. In: Liben LS, Signorella ML, Eds. Children's gender schemata. Pennsylvania State University. San Francisco 1987; pp. 57-73.

Baumert J. Koedukation oder, geschlechtertrennung. Zeitschrift furpadagogik 1992; 38: 83-110.

Lawrenz F. Gender effects for student perception of the classroom psychosocial environment. J Res Sci Teach 1987; 24: 689-97.

Hopf D, Hatzichristou C. Teacher gender-related influences in Greek schools. Br J Educ Psychol 1999; 69: 1-18.

Ritter DR. Teacher's perceptions of problem behavior in general and special education. Except Child 1989; 55: 559-64.

Jones, MG, Wheatley, J. Gender differences in teacher-student interactions in science classrooms. J Res Sci Teach 1990; 27: 861-74.

Good TL, Sikes JN, Brophy JE. Effects of teacher sex and student sex on classroom interaction. J Educ Psychol 1973; 65: 74-87.

Younger M, Warrington M. Differential achievement of girls and boys at GCSE: some observations from the perspective of one school. Br J Sociol Educ 1996; 17: 299-314.

Arnot M, David M, Weiner G. Educational Reforms and Gender Equality in Schools. Equal Opportunities Committee. Manchester 1996.

Turner E, Riddell S, Brown S. Gender equity in Scottish schools: the impact of recent educational reforms. Equal Opportunities Commission. Manchester 1995.

Riddell S. Boys and under-achievement: the Scottish dimension. Inter J Inclu Educ 1998; 2: 169-86
Harris S, Nixon J, Rudduck J. Schoolwork, homework and gender. Gend Educ 1993; 5: 3-15.

Rudduck J, Chaplain R, Wallace G. School improvement: what can students tell us? David Fulton. London 1995.

Younger M, Warrington M, Williams J. The gender gap and classroom interactions: reality and rhetoric? Br J Sociol Educ 1999;20:325-41.

Gipps C. Review and conclusions: a pedagogy or a range of pedagogic strategies? In: Murphy PF, Gipps CV, Eds. Equity in the classroom: towards effective pedagogy for girls and boys, Farmer Press. London 1996; pp. 260-71.

Williams M, Burden R, Lanvers U. 'French is the language of love and stuff': student perceptions of issues related to motivation in learning a foreign language. Br Educ Res J 2002; 28: 503-28.

Burstall C. Factors affecting foreign language-learning: a consideration of some relevant research findings, Language Teaching and Linguistics Abstracts. 1975; 8: 105-25.

Head J. Gender identity and cognitive style. In: Murphy PF, Gipps CV, Eds. Equity in the classroom: towards effective pedagogy for girls and boys, Falmer Press. London 1996; pp. $59-70$.

Ropers-Huilman B. Constructing feminist teachers: complexities of identity. Gend Educ 1997; 9: 327-43.

Weiler K. Women teaching for change: gender, class and power. Bergin and Garvey. New York 1988.

Jules V, Kutnick P. Student perceptions of a good teacher: the gender perspective. Br J Educ Psychol 1997; 67: 497-511.

Haertel GD, Walberg HJ, Haertel EH. Socio-psychological environments and learning: a quantitative synthesis. Br Educ Res J 1981; 7: 27-36. 